\title{
THE NICHE TOURISM DEVELOPMENT OF ONE OF THE MOST MYSTERIOUS FORESTS IN ROMANIA: THE HOIA-BACIU FOREST
}

\author{
Marius-George OPREA \\ Babeş-Bolyai University, Cluj-Napoca, Faculty of Geography, ROMANIA \\ marius.oprea@geografie.ubbcluj.ro \\ Marius-Cristin LAZIN \\ Hoia-Baciu Project, Romania - Your Lifetime Experience NGO, Cluj-Napoca, ROMANIA \\ hoiabaciu@gmail.com
}

Elena-Cristina MARTIUC

Tourist Information Center, Cluj-Napoca, ROMANIA

cristinamartiuc@yahoo.com

DOI: http://dx.medra.org/10.23740/TID120165

\begin{abstract}
During the last few years, the Hoia-Baciu Forest, located near Cluj-Napoca, in Transylvania, Romania, has started to attract the attention of the local community after being included in diverse TOPs of the most haunted and creepiest places in the world, alongside other areas with similar phenomena. It became famous in 1968, when several people captured on a camera a flying object which was categorised by the professionals as UFO. Hoia-Baciu continues to fascinate and we want to emphasise its profile: is it a tourist destination yet or just a popular forest among locals, for picnics or other leisure activities? What should be done to transform it in a niche tourism destination? In order to find out, we analysed the data of the Hoia-Baciu Project, designed (by the local Romania - Your Lifetime Experience NGO) to include this mystical forest in the tourist circuit: tourist demands (06.2014-06.2016), activities for locals (2014-2016) and the results of a photo contest meant to answer to the question "what does the Hoia-Baciu Forest mean to me?" (2016). We also analysed the demands for the Hoia-Baciu Forest at Cluj-Napoca Tourist Information Center, in comparison to the total demands and the number of tourist arrivals in Cluj-Napoca. We answered why the Hoia-Baciu Forest is a niche destination for dark and paranormal tourism (among tourists) and just an ordinary attraction for locals.
\end{abstract}

Keywords: niche tourism, dark tourism, paranormal tourism, new tourist attraction, haunted forest, intergalactic park

\section{INTRODUCTION}

The concept of niche tourism has emerged in recent years in counter-point to what is commonly referred to as mass tourism. "The term 'niche tourism' is largely borrowed from the term 'niche marketing'. [...] In marketing terms, niche refers to two inter-related ideas. First that there is a place in the market for a product, and second, there is an audience for this product, where both place and audience are seen to be particular entities" (Robinson \& Novelli, 2005, p. 4). This is then a result of the idea of niche tourism products.

Destination Development through Niche Tourism can help to create a brand and image of a mysterious place, providing a major motivating factor for tourists to visit a destination. A proposal for the local authorities would be to promote the forest as a niche destination for dark or paranormal tourism, so it can become a tourist attraction by itself in Cluj-Napoca. The concept 
of dark tourism, is considered the act of trips and places to visit, of attractions and performances that have as main theme of mystery, macabre and death, real or reconstructed (Minić, 2012).

Benefiting from the national and regional brand Transylvania - Dracula, Romania is one of the most important tourist destinations that are based on the concept of dark tourism (Hovi, 2013). Mysterious places and legends often awake visitors' interest and this can be seen in the case of destinations that promote Dracula, such as the Bran Castle (the most visited attraction in Romania), Sighişoara (Dracula's place of birth), or Borgo Pass (also related to Dracula's legend). The events built upon malefic characters, or based on myths or legends, attract many people, such as in the case of the UNTOLD festival, which took full advantage of the reputation of Transylvania and its mysterious places. If Transylvania benefits from this reputation of a mysterious land, why Cluj-Napoca will not become a niche destination for those who want to discover the mysteries of the Hoia-Baciu Forest? (Rabontu, 2014).

Located in South-Eastern Europe, in Transylvania, near Cluj-Napoca (Figure 1), the forest covers an area of about 1 square mile ( 2.95 square kilometres). Its southern border begins on a ridge which runs east-west. It lies out of the steep southern slope of the hill, which rises from the Someșul Mic River. To the north, the forest ends on a smoother slope, which meets the Nadăs River. The eastern end of the forest is bordered by the Tăietura Turcului, an artificial valley that divides the hill from north to south and hosts a road. The west end of the forest reaches the north-eastern slope of the Dealul Melcilor, nearby the Mujai Forest, which extends further westward. The Bongar Valley runs along the south end of this side, which contains a downy oak grove, unique to the southern steppe. A part of the north-eastern end of the forest is bordered by Valea Lungă (The Long Valley), which passes through Eocene limestone and forms Cheile Baciului, a valley with asymmetric slopes. A small natural lake is located upstream from Cheile Baciului, at the border of the forest. There are several springs with potable water at the north edge of the forest, in Valea Lungă.

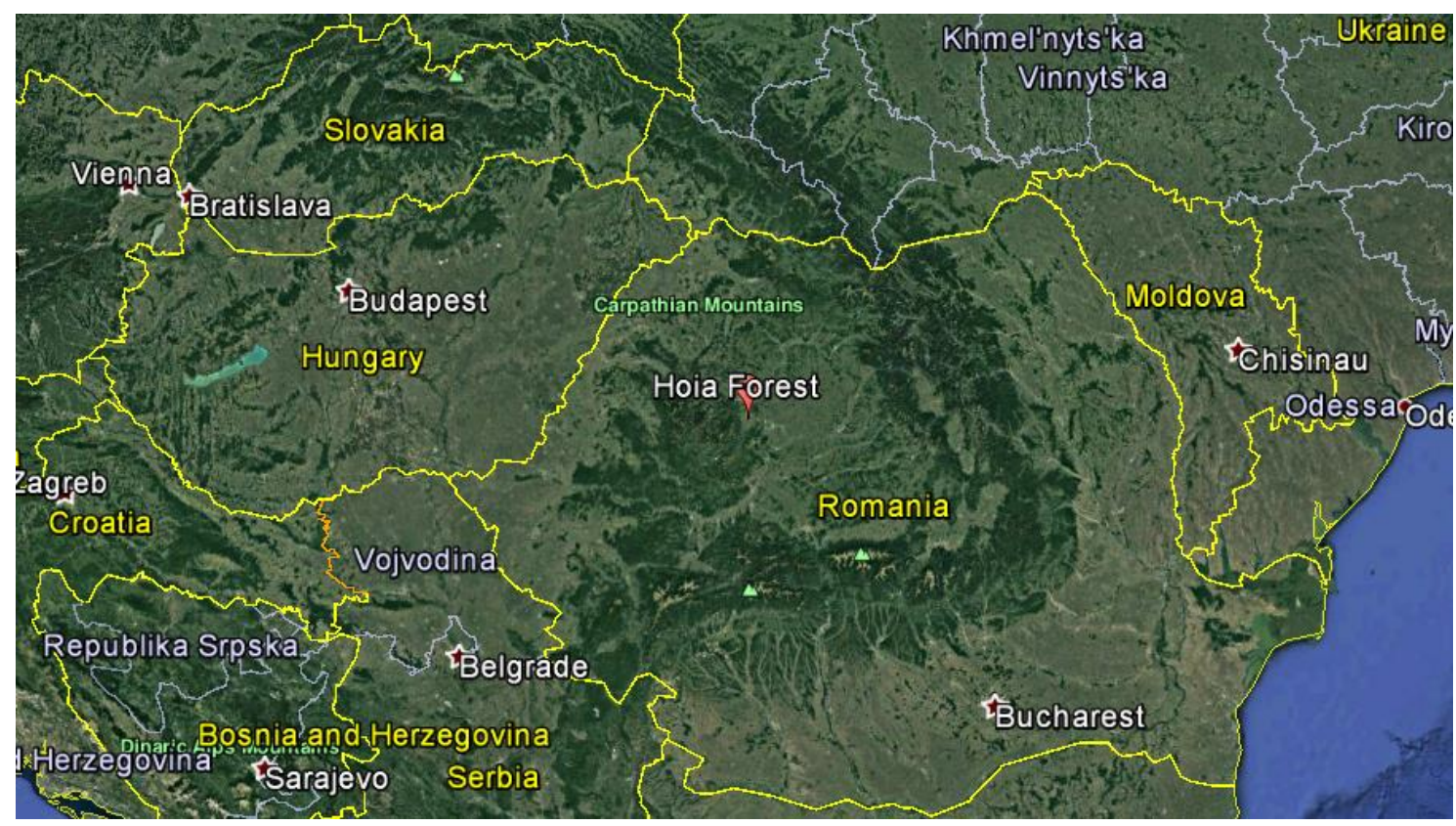

Figure 1: The location of the Hoia-Baciu Forest 
The Hoia-Baciu Forest enjoys the attention and interest of the media and international researchers since 1968, when the military technician Emil Barnea caught, in some of his photographs, a flying saucer over the place called "Poiana Rotundă", which became one of the locations of major interest in the forest (Pătruț, 1995, pp. 17-18). His photographs were later known worldwide and are considered to be some of the best photographs that ever captured a flying saucer.

Subsequently, Hoia-Baciu was researched by worldwide specialists such as ufologists, professional photographers, parapsychologists, yoga practitioners, and biologists (Pătruț, 1995, pp. 16-17, 56$60)$, the phenomena they captured awakening journalists', other researchers', and paranormal enthusiasts' interest, but, because of the lack of information from the field (there are no panels, no maps, no pedestrian trails or other information), they are hardly getting to the areas listed in the books written by those who have dedicated years of their career studying the forest.

Lately, important TV stations like BBC $\quad(2012.12 .03 \quad-$ http://www.bbc.com/travel/story/20121203-worlds-most-haunted-forests), Travel Channel (Ghost Adventures Season 8, Episode 12 - Halloween Special Transylvania http://www.paranormalpopculture.com/2013/11/ghost-adventures-recap-transylvania.html) and travel magazines or other important publications such as Travel \& Leisure (2012 http://www.travelandleisure.com/slideshows/worlds-most-haunted-forests) and The Guardian (2013.10.29 - https://www.theguardian.com/travel/2013/oct/29/halloween-holiday-top-10scariest-europe) made several tops with haunted places around the world, putting the Transylvanian forest in one of the first five places, beside the Aokigahara Forest (Japan), the Black Forest (Germany), and the Wychwood Forest (England), catching the attention of all those interested in mysterious spots around the globe, setting the directions of a new type of tourism (i.e. the dark tourism) in Cluj-Napoca, but famous already in Transylvania.

The aim of our research was to investigate the profile of the forest as destination, to know if it was perceived just as a common forest around a city (mostly appreciated for picnics, sports, or other leisure activities) or it started to become a destination for dark or paranormal tourism. Another research question we wanted to answer to was what should be done in order to transform the forest into a niche tourism destination?

\section{METHODOLOGY}

In order to answer to our questions regarding the profile of the Hoia-Baciu Forest as a tourist destination, first, we analysed the data of the single official project dealing with the Hoia-Baciu Forest: the Hoia-Baciu Project (Romania - Your Lifetime Experience NGO).

The Hoia-Baciu Project was born in January 2012, having as main goal the promotion and integration of the Hoia-Baciu Forest in the tourist circuit.

Since the beginning of the project, no data was registered until 2014, this being one of the limits of this research. The information analysed first refers to the tourist demands addressed to the Hoia-Baciu Project Team, regarding the forest: ways to get there, interest points, nearby parking lots, history, stories and legends about the forest, representative pictures for the phenomena hosted by the forest since 1968 onwards, pieces of advice for visiting the forest, tours, or other useful information for those interested in mysticism, paranormal and activities in nature.

The second analysis focused on the data regarding the activities realised in the forest by the Hoia-Baciu Project Team (e.g. yoga sessions, escape games, meditation sessions, team-building, etc.), involving the local community. 
The third analysis refers to a photo contest meant to answer to the question "what does HoiaBaciu Forest mean to me?" In this contest, we asked the local community to send us pictures representing their vision regarding the Hoia-Baciu Forest (We received 24 pictures).

Finally, we analysed the demands for Hoia-Baciu Forest registered at Cluj-Napoca Tourist Information Center, in 2015, and also the number of tourist arrivals in Cluj-Napoca for the entire period of the study.

\section{RESULTS}

\section{The birth of a new attraction: the Hoia-Baciu Forest}

The Hoia-Baciu Forest is one of the most controversial and mysterious places in Romania, hosting a whole series of phenomena, at least since August 1968. A mystery, by definition, is "anything that is kept secret or remains unexplained or unknown; any truth that is unknowable except by divine revelation" (http://www.wordreference.com/definition/mystery). Mysteries can activate humans' curiosity, a psychological phenomenon appearing when there is a gap between what people know about something and what they would like to know. The lack of information related to mysterious places can attract people and make them want to discover more.

In 2012, on the background of a massive potential promotion of the forest made by the international mass media, a new project was born: the Hoia-Baciu Project. It was initiated by Romania - Your Lifetime Experience Association from Cluj-Napoca and has as main goal to rise awareness of the Hoia-Baciu Forest among locals and foreign visitors interested in mysteries, mystical and paranormal activities and destinations, to include the forest in the local tourist circuit and, later, in the regional tourist circuit of the mystical and mysterious places in Transylvania.

The secondary objective of the project was to save the forest from the illegal wood cutting, from the illegal waste disposal, and the chaotic expansion of the civil constructions at the edge of the forest.

\subsection{A new urban space for Cluj-Napoca}

The Hoia-Baciu Project Team has attracted the local community to the forest (since 2014) through escape games (about 600 people), cleaning campaigns (about 80 people), tours (about 400 people), workshops (about 40 people), yoga sessions (about 130 people), and through a few other activities (about 60 people).

The Hoia-Baciu Forest became, especially since 2014, a space for outdoor activities: sport, orientation workshops, picnics, horse riding, geocaching, paintball, downhill mountain bikes, and cycling. The activities initiated by the RYLEx Association managed to gather the local community into this mysterious and beautiful place, providing the community with the opportunity to learn about the tourist potential of the forest.

\subsection{A new tourist attraction in Cluj-Napoca}

The attention paid to the forest in the last few years transformed it in the first paranormal attraction from Cluj-Napoca, having also potential for active tourism (http://www.darktourism.com/index.php/18-main-menus/mainmenussubpages/611-paranormal-tourism). 
In 2015, the Hoia-Baciu Project Team organised the photo contest to see how the forest was perceived locally: 7 out of 24 pictures presented the forest in a friendly way (simple nature landscapes, a place for relaxation, for walking dogs or for horse riding) while the rest of 17 pictures presented the forest as dark, mysterious, mystic, or paranormal (a lot of fog, weird trees, parallel realities, paranormal phenomena, or apparitions). In conclusion, the locals perceived the forest as being different, not just an ordinary location for picnics and outdoor activities.

Still in 2015, Cluj-Napoca Tourist Information Center received requests from 8,794 visitors which were interested to take maps, materials and information about the city, the demand for HoiaBaciu Forest representing about $1 \%$ from the total (Figure 2), confirming that Hoia-Baciu Forest is a new attraction in Cluj-Napoca, a destination for niche tourism (dark and paranormal tourism).

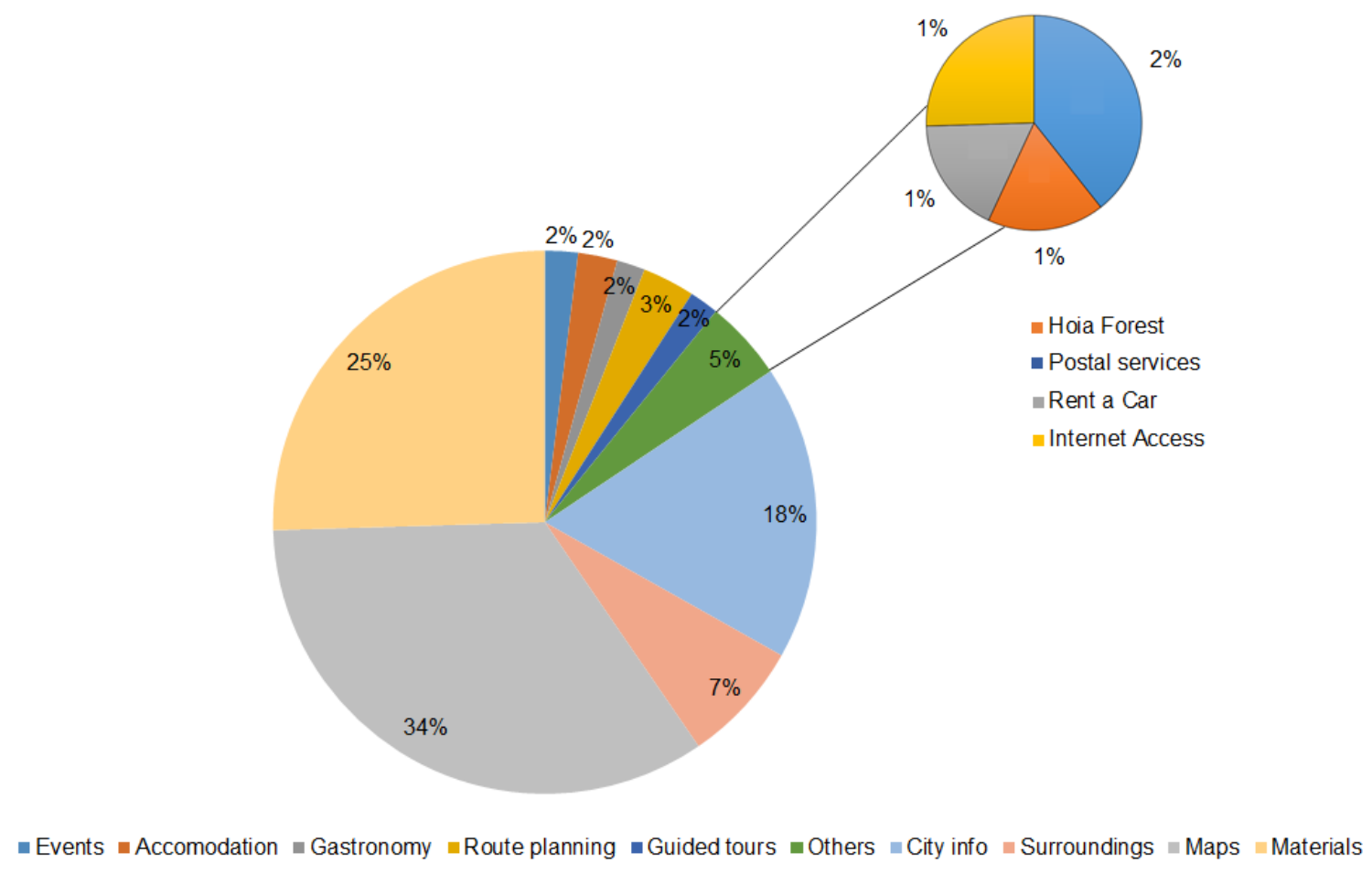

Figure 2: Tourist Information Center requests in 2015

Source: Oprea \& Lazin (2016), according to data from the Tourist Information Center, Cluj-Napoca

The Hoia-Baciu Forest is close to be an alternative for the tourist offer of the city, unattractive nowadays for those tired of the urban environment. Until now, there are a few tourist products which slowly got shape: day photo tours; night photo tours; yoga sessions; escape games; team building activities; meditation sessions; archery \& clay pigeon shooting. All these products can be provided now by the Hoia-Baciu Project Team and its partners.

The idea of including the forest in the local tourist circuit (Figure 3 ) involves a lot of institutions and private land owners, because the forest is divided administratively between Cluj-Napoca City and the communes Baciu, Florești, and Suceagu. 


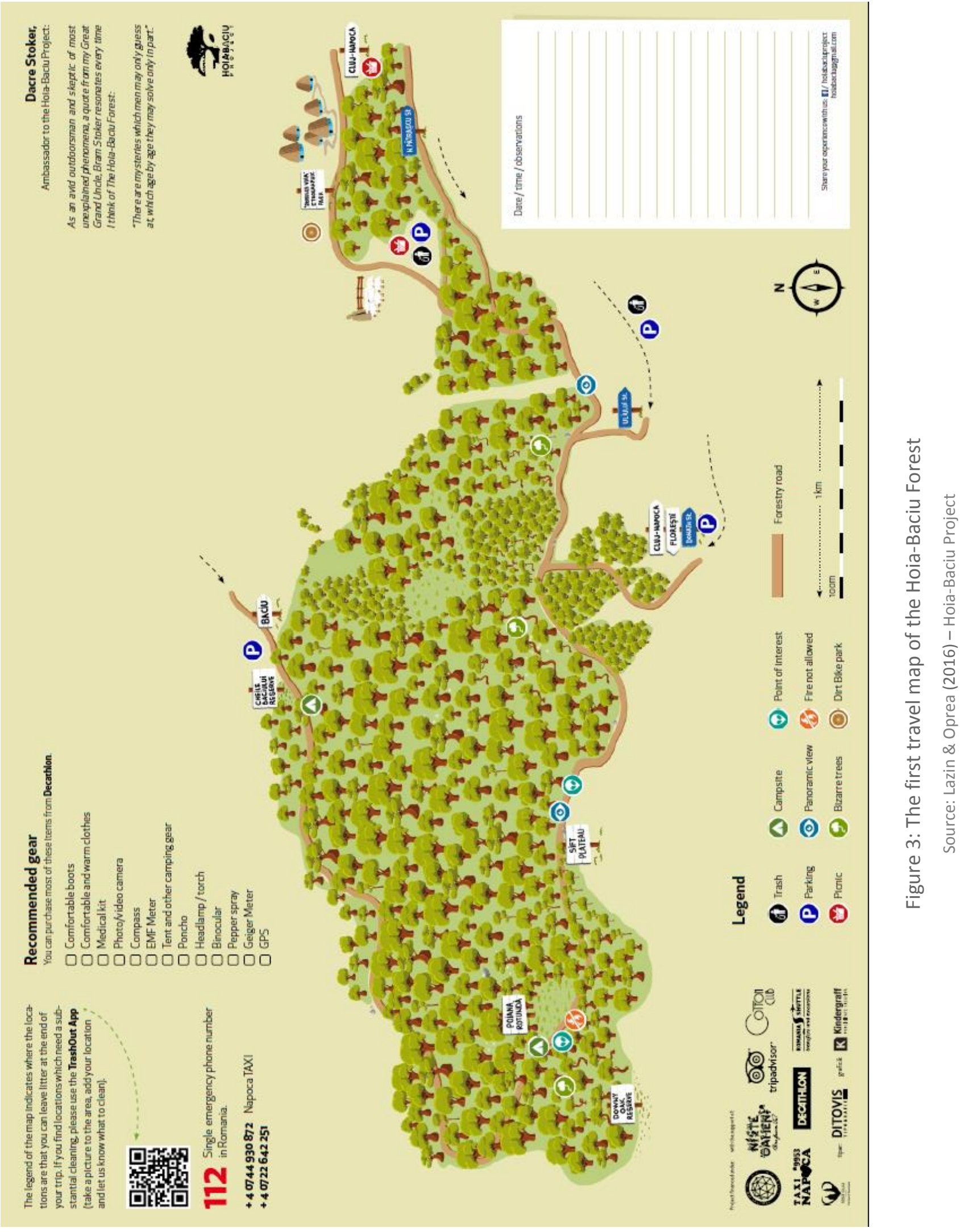


Being a complex and long-term project, the Hoia-Baciu Project Team has made the forest more accessible to a larger number of potential visitors, by creating the first travel map of the HoiaBaciu Forest, now distributed in the tourist information centres in Cluj-Napoca and in few accommodation units.

The map suggests an itinerary and contains information regarding the access to the forest, the recommended gears, trash storage, campsites, points of interest, parking lots, picnic sites, and other useful information for a forest visitor.

\subsection{A new global destination}

Media caught the international attention by intensive and slightly exaggerated promotion of the phenomena manifested in Hoia-Baciu, since 2012, promoting the forest as a "must see" attraction in Transylvania, such as the famous Dracula novel, written in 1897 by the Irish Bram Stoker. Now, Dacre Stoker, Bram Stoker's great-grandnephew of became the world ambassador of the Hoia-Baciu Project, spreading the word especially in the United States which represent the country from where the majority of those interested in the forest came from.

Analysing the tourist demand for Hoia-Baciu Forest during the last few years (Figure 3), we can notice a small, but increasing demand for each month (about information regarding ways to get there, points of interest, nearby parking lots, history, stories and legends about the forest, representative pictures for the phenomena hosted by the forest since 1968 onwards, advice regarding visiting the forest, tours or other useful information for those interested in mysticism, paranormal and activities in the nature)(Figure 4).

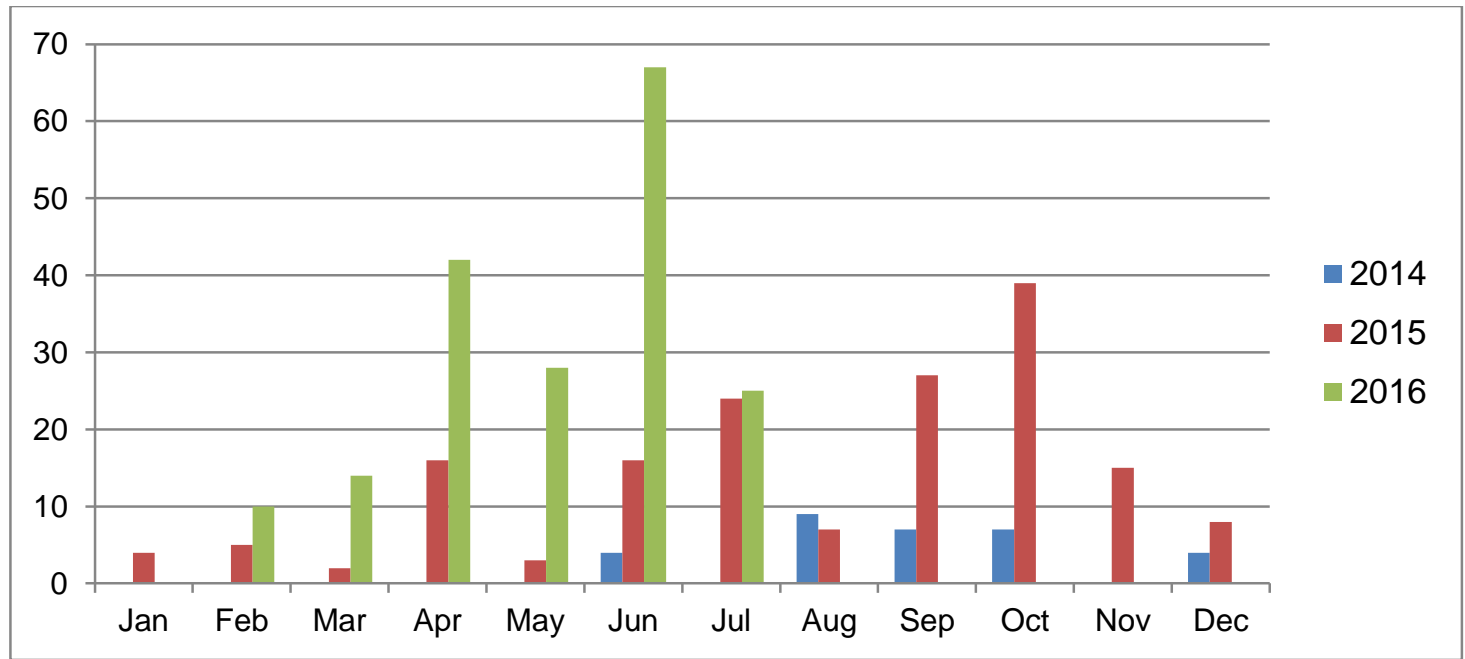

Figure 4: Tourist demands each month for Hoia-Baciu Forest, 2014-2016

Source: Lazin \& Oprea (2016) - Hoia-Baciu Project

There were 657,140 tourist arrivals in Cluj-Napoca in the same period (06.2014-06.2016), meaning that those interested in Hoia-Baciu Forest represented $0.06 \%$ of the total. In 2016, it was a growth in the Hoia-Baciu Forest demand, due to awareness increase of the Hoia-Baciu Forest worldwide, especially in Europe, and also among locals. These numbers confirm that the Hoia-Baciu Forest slowly becomes a niche tourism destination. 
Moreover, since 2012, the Hoia-Baciu Project Team got lots of messages from people all around the world, asking for directions, information or the tour of the forest.

Regarding the countries of origin of the requests, one can notice American tourists' high demand, where the niche paranormal tourism is more developed (Figure 5); the Romanians' interest is average due to the forest promotion in the recent years.

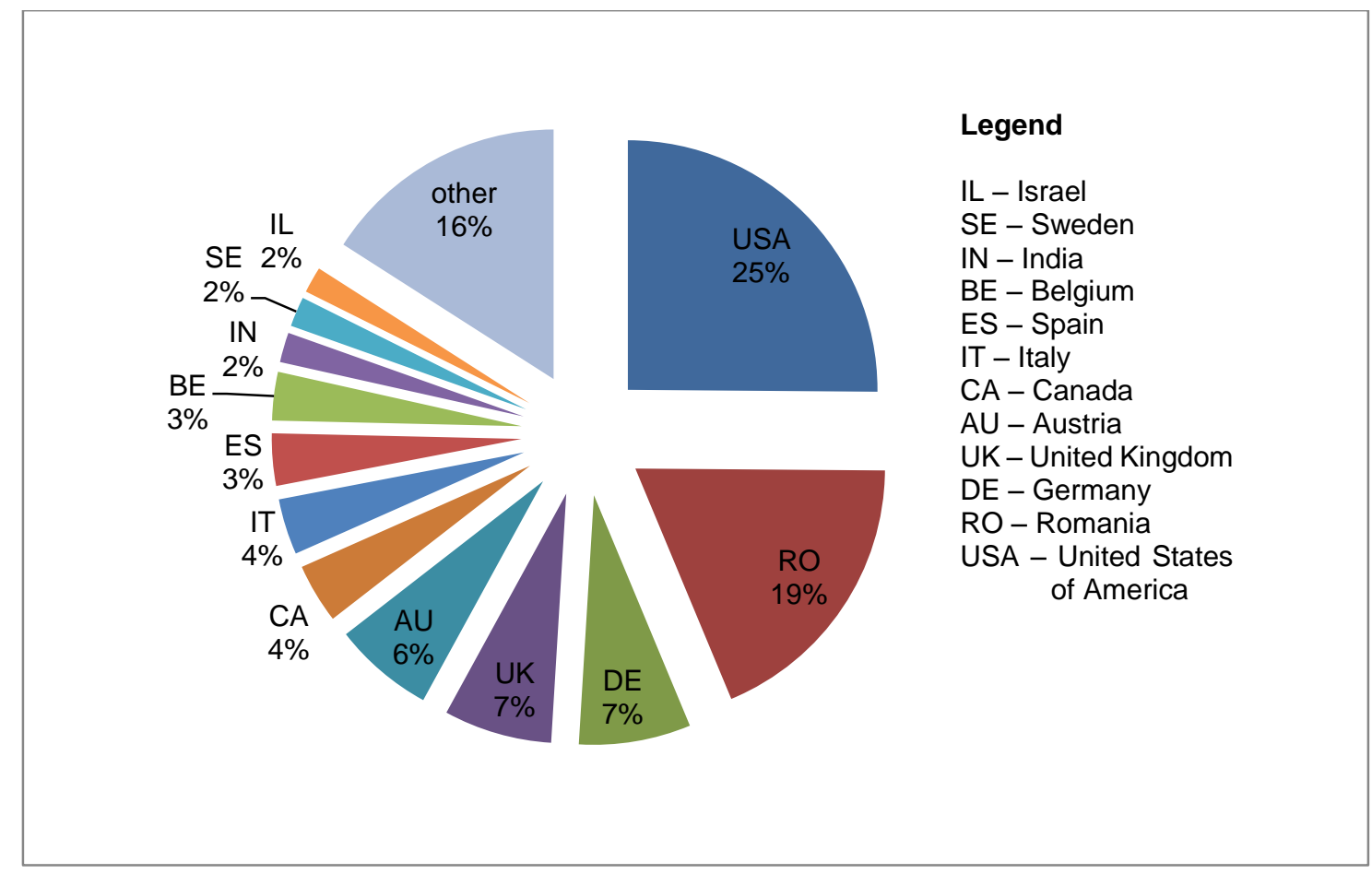

Figure 5: Tourists' demand for the Hoia-Baciu Forest (by countries of residence), 2014-2016

Source: Lazin \& Oprea (2016) - Hoia-Baciu Project

\section{The role of niche tourism products in destination demand}

Most studies examining the image and positioning of a destination have followed the traditional approach based on image creation, through attributes that reflect most attractive products of the respective destination. However, it has been suggested (Ali-Knight, 2011, pp. 14-15) that for effective destination positioning it is important to first identify the attributes that the visitor perceives as being important and then those that are unique and differentiate it from other destinations. Therefore, the identification and analysis of these attributes incorporated with personal variables such as the tourist needs can help to identify the potential niche markets that could be used to develop the destination (Ali-Knight, 2011, pp. 14-15). The use of well-developed niche based products can lead to the growth of market share of a destination.

Niche tourism is, therefore, a response to an increasing demand for more sophisticated tourist products. It is a means by which destinations can differentiate their tourist products and compete in a challenging and cluttered tourism environment. 


\section{DISCUSSION}

Results show that, slowly, the Hoia-Baciu Forest is on the right track to become a new tourist destination. Though, there are a few changes needed by both Cluj-Napoca and the forest in order to attract more visitors in the area.

In recent years, tourism, in Cluj-Napoca, has been very dynamic and the authorities and the local actors have encouraged the development of tourist activities and cultural events in order to increase the tourists' average length of stay.

In order to develop Cluj-Napoca as a city-break destination, there are a number of proposals regarding tourism development in the area, one of them being the tourist development of the Hoia-Baciu Forest area. Authorities and the local actors can benefit from the intense mediatisation of the Hoia-Baciu Forest, this being highly beneficial in order to diversify the tourism offer in the region.

A first proposal would be to protect the area and to transform the forest into a metropolitan park that will run by the rules of a natural park, so that the trees and the landscapes would benefit from an increased protection. For a better preservation of the area, a ranger service can be set up which can supervise the perimeter of the forest, and also mark few thematic tourist routes, thus including the forest in a tourist circuit.

Another proposal would be to diversify the tourist services in the area, through guided tours of the forest, correlated with city tours, which can combine the urban legends with the mystery of the forest. Also, being a green area, special horse-riding/eco touristic tours might be implemented so that tourists enjoy a unique experience. Around the forest, there are several sheepfolds, which are also part of the legend of the forest (a folklore legend about the Hoia-Baciu Forest says that a shepherd disappeared together with his 200 sheep somewhere around the forest), enabling them to capitalise their organic products in site, by introducing them into the guided circuit, and, thus, the community will directly benefit from the flow of tourists in the area.

The proposal of the Association Cluj-Napoca 2021 - European Capital of Culture regarding the construction of an intergalactic theme park close to the forest, as continuation of "Romulus Vuia" Ethnographic Park (the oldest ethnographic park in Romania), would connect both, the traditional ethnographic park goals and the futurist designed spaceships. This target area may confer a greater range of attractions and tourist services, and would address to the mass tourism. Another service that may be offered in the park is overflying the area in a hot air balloon that would be alien custom shaped, so tourists would remain with a unique memory. These projects can be realised even if Cluj-Napoca does not win the title of European Capital of Culture in 2021.

Not least, the events have an important role in the tourism development of the forest, either smaller niche events, or larger events such as the music festival Delahoya (the oldest electronic music festival in Romania) or Mioritmics, which gather a large number of visitors close to the Ethnographic Park. Untold festival (the best major festival in Europe in 2015) had 240,000 participants in 2015 and 300,000 in 2016, and took place downtown. A stage located in the HoiaBaciu Forest area would be a great way to promote the forest through events, but it should be done carefully, because we would recommend a limited number of visitors in the forest and smaller cultural events such as the Night of Nightingales, film screenings or sports events like marathons (Alien Run/Ghost Run), horse riding or archery can have a huge success among both locals and visitors. 


\section{CONCLUSIONS}

The profile of the Hoia-Baciu Forest is still uncertain, but we have seen that slowly it is changing into a new urban space for Cluj-Napoca, into a new local tourist attraction, and into a global niche tourism destination.

In order to become a fully independent attraction and destination, there are still a few more steps to be taken, such as: protecting the forest (from illegal wood cutting, from the waste disposal and from the new constructions), maintaining its mystery and mysticism, including the forest in the network of events, festivals and attractions and offering some unique niche tourist services to the potential visitors.

We believe that the mysterious Hoia-Baciu Forest has a great potential for development in terms of tourism and, along with popular brands such as Transylvania and Dracula, it might become a worldwide destination. If the local authorities would implement our proposals, the tourists' length of stay in Cluj-Napoca might be increased, and also Cluj-Napoca and the Hoia-Baciu Forest might become a destination known worldwide.

\section{REFERENCES}

ALI-KNIGHT, J.M. (2011). The Role of Niche Tourism Products in Destination, PhD by Published Works, Retrieved June 23 2016, from http://researchrepository.napier.ac.uk/5376/1/Full_thesis.pdf

HOVI, T. (2013). Dark tourism - from Auschwitz to Dracula, Retrieved June 20 2016, from http://turunmatkailuakatemia-fibin.directo.fi/@Bin/8fd022501f6a8809cd7208237c7ab5fe/1478703743/application/pdf/139967/ Dark\%20tourism\%20Matkailuakatemia\%20Hovi.pdf

http://www.bbc.com/travel/story/20121203-worlds-most-haunted-forests, Retrieved June 182015.

http://www.dark-tourism.com/index.php/18-main-menus/mainmenussubpages/611-paranormaltourism, Retrieved June 182015.

http://www.paranormalpopculture.com/2013/11/ghost-adventures-recap-transylvania.html, Retrieved June 182015.

http://www.travelandleisure.com/slideshows/worlds-most-haunted-forests, Retrieved June 182015.

http://www.wordreference.com/definition/mystery, Retrieved June 182015.

https://www.theguardian.com/travel/2013/oct/29/halloween-holiday-top-10-scariest-europe, Retrieved June 182015.

MINIĆ, N. (2012). Development of "Dark" Tourism in the Contemporary Society. Journal of the Geographical Institute Jovan Cvijic, 62(3), 81-103, Retrieved July 21 2016, from http://www.doiserbia.nb.rs/img/doi/0350-7599/2012/0350-75991203081M.pdf

PĂTRUȚ, A. (1995). Fenomenele de la Pădurea Hoia-Baciu. Cluj-Napoca: Editura Divia.

RABONTU, C.I., \& VASILE, M.C. (2014). Dark Tourism - New Form of Tourism in Romania. Annals of the "Constantin Brâncuşi" University of Târgu Jiu, Economy Series, 6, 269-273, Retrieved June 21 2016, from http://www.utgjiu.ro/revista/ec/pdf/2014-06/52_Rabontu,Vasile.pdf

ROBINSON, M., \& NOVELLI, M. (2005). Niche Tourism: An Introduction. In: NOVELLI, M. (ed.), Niche Tourism: Contemporary Issues, Trends and Cases (pp. 1-11). Routledge. 